called on to play an important part in producing such an aptitude for early devclopment, since all must essentially result from the nature and action of alimentation, must be one of the first to undergo modifications."

We do not question this conclusion, but the teeth and horns seem at present to have been slightly influenced by the "improvements" we have been considering. It is true that the art of breeding can greatly modify the horns; it can, in fact, obliterate them in horned cattle, and produce them in the hornless breeds, but this is quite apart from early maturity, which does not necessarily modify to any great extent, or with any certainty, either the horns or the teeth. Occasional examples of a very early development of the teeth, such as M. Regnault describes, do sometimes occur, but they are so rare as to be regarded as abnormal, and the rule, with the improved as with the older breeds of cattle, is that they produce two permanent teeth at two years old, and two others each year till they are five years old, when they are, as farmers say, "fullmouthed." It is not improbable, however, that the not very unfrequent appearance of the first permanent teeth at less than two years old, as well as the irregular dentition of highly-bred pigs, are manifestations that further and future changes may still be anticipated. Among many useful agricultural pamphlets that have been issued from the office of The Field, it is stated that one will appear shortly on "The Early Maturity of Live Stock."

H. E.

\section{THE BORNEO COAL-FIELDS}

HAVING recently visited some of the coal-fields in the Island of Borneo, it may be interesting to your readers to know the result. The subject was one of special interest to me, and its investigation was one of the principal objects I proposed to myself in my travels in the East. Just before leaving Australia I had published in the Proceedings of the Linnean Society of New South Wales a complete history of the known coal flora of Australia, and a review of its geological position. The relation of the Australian to the Indian coal flora is well known. It seemed hardly possible that in Borneo, where such extensive coal-formations exist, but that some connecting link would be found between Australia and India.

The subject is very little known. The late Mr. Motley had the management of the Labuan Mines. His are the only writings on the age of the Borneo coal which are known to me. What he wrote is quoted by Mr. Wallace in his work on "Australasia." He regarded the beds as Tertiary, and the fossils as of species of plants and marine mollusca now living on the coast. He speaks of cocoanuts and the.peculiar winged seeds of Dipterocarpus (so common in Borneo) being common also in the coal at Labuan. He thought that the beds evidently originated in the most recent times from masses of drift-wood brought down by the rivers and stranded on the coast, in the way the traveller sees so often repeated on the Borneo coast at the present day. He also stated that the Labuan coal was not, properly speaking, coal, but more Jike driftwood partially bituminised.

Mr. Motley subsequently was killed by the natives at Banjermassim. It is now six or seven years since the mines at Labuan have been worked. I am not sure that he had the same impressions about the South Borneo coal as of the Labuan beds, but I think J am not far out in thinking that he regarded all Borneo coal-beds as belonging to one immense Tertiary formation.

There are few countries of the world, except, perhaps, Eastern Australia, where coal is so extensively developed as in Borneo. Thick seams crop out in innumerable places on the coast and on the banks of the rivers. In some of the streams of North Borneo I have seen water- worn and rounded fragments of coal forming the entire shingle bed of the channel. In some places, again, there are outcrops with seams of good coal 26 feet thick. The coal-formation is the one prevailing rock of the coast. It forms the principal outcrop about Sarawak. At Labuan, also, no other rock can be seen. Lining the banks of the Bruni River, I only saw picturesque hills of very old Carboniferous shale. All the grand scenery of the entrance to the port of Gaya is made up of escarpment of coalrocks. At Kirdat it is the same, and so I might go on with a long list of coal-bearing localities.

Now, in such a large island as Borneo, with such a wondrous mountain system, it would be absurd to suppose that all this coal belonged to one age. We might as well suppose the same of the comparatively small islands of Great Britain, and yet what an error that would be. In Eastern Australia and in Tasmania, beds of coal of very different age lie close together. I have found the same in Borneo. Whether there is Tertiary coal or not in the island, I cannot say; but there is Mesozoic coal, and probably Palæozoic coal, and coals like those of Newcastle in Australia, whose position hovers between the true Palæozoic and the Trias. To begin with Labuan: the works there have been long since abandoned; the adits are partly filled with water, and the shafts have fallen in, so that it is next to impossible to explore the mine now. But there is plenty of coal and shale on the surface, and there are excellent sections on the sea-cliffs close by. The formation is a drifted sandstone with much false bedding. It contains not a trace of lime or any marine organism. Under the microscope the siliceous grains are seen to be rounded. I think it is an Eolian formation with lines of rounded pebbles of small size. The whole deposit is very similar to the Hawkesbury sandstone of Australia, which is of Oolitic age. In both formations there are roots and carbonised fragments of coniferous wood, in which the tissue is still to be traced. The coal on the surface is a truly bitumenised coal, very brittle, and like what we get in the same rocks in Australia. The few plant-remains I saw were not referable to any known genus ; they were like Zygophyllites, and perhaps these are the plants which have been identified as wings of Dipterocarpus, which they remotely resemble.

I saw no marine fossil, and the absence of any lime in the beds makes one think that those which were discovered did not come from any of the strata which are exposed in section. Sir Hugh Low, who resided many years at Labuan, gave me some casts of marine fossils taken from the locality. They were casts not easily identified, and certainly not like any now existing of the coast. The molluscan fauna of the locality is that of the usual Indian Oceanic type, with a slight admixture of Chinese and Philippine forms. In all recent bcach remains in these parts of the world there is a large admixture of urchins, corals, \&c. The aspect of the matrix was not of this character. It was much more like a blue-clay such as we have in Australia above the Mesozoic coal.

On the whole, I am inclined to regard the Labuan beds as of Oolitic age, and not Tertiary. Of the value of the coal-seams I had no means of judging. The amount on the surface showed that there was plenty to be had. Labuan is a naval coaling station. Stores of coal are brought out from England at a great expense for the use of her Majesty's navy, and if the same thing could be got in the island the enormous advantages are obvious. I think it should be further tested.

About fifty miles away to the sonth-east is the mouth of the Bruni river. Here the rocks are quite of a different character and much older. They are sandstones, shales, and grits, with ferruginous joints. The beds are inclined at angles of 25 to 45 degrees. They are often altered into a kind of chert. At Moarra there is an outcrop of coalseams 20,25 , and 26 feet thick. The coal is of excellent quality, quite bituminised and not brittle. The beds are 
being worked by private enterprise. I saw no fossils, but the beds and the coal reminded me much of the older Australian coals along the Hunter River. The mines are of great valuc. They are rented for a few thousand dollars (by two enterprising Scotchmen) from the Sultan of Bruni. The same sovereign would part with the place altogether for little or nothing. Why not have our coaling station there? Or what if Germany, France, or Russia should purchase the same from the independent Sultan of Bruni?

The Sarawak coal beds I did not visit, but a collection of fossils was kindly sent to me by the Hon. Francis Maxwell, the Resident. I recognised at once well-known Australian and Indian forms, such as Phyllotheca australis and Vertebraria. These are entirely characteristic of the Newcastle deposits in New South Wales. The connection thus established between the Carboniferous deposits of India, Borneo, and Australia is exceedingly interesting.

I intend to publish in another form all the observations $I$ have made on the coal formations of Borneo and their included fossils. The main result of all I have seen may be embodied in the following conclusions:-

(I) There are in Borneo immense coal deposits of very differcnt ages.

(2) These formations extend from the Palæozoic to the Middle Mesozoic periods.

(3) The fossils from some of the beds are specifically identical with those of certain well-known forms common to India and Australia.

(4) The Labuan coals are probably of Oolitic age, and not connected with any marine formation, but apparently of Eolian origin.

Labuan, Borneo, November 25, 1884

\section{THE PARIS CENTRAL SCHOOL OF ARTS $A N D$ MANUFACTURES}

A RECENT article in La Nature describes the A new buildings of the École Centrale des Arts et Manufactures. The school was founded in 1829 for 200 pupils by Dumas, Lavallée, Péclet, and Olivier. The buildings remained from that date until quite recently in the rue de Thorigny, but the want of space became more and more perceptible as the scheme prospered, and in 1874 the Council proposed that the old buildings should be abandoned, and new ones erected on a vacant plot of ground 6300 square metres in extent, the site of the old St. Martin's Market, which abutted on four streets. The principal advantage of this situation was that it faced the garden of the Conservatoire des Arts et Métiers, and was therefore within reach of the immense technical treasures of that establishment. The new buildings have

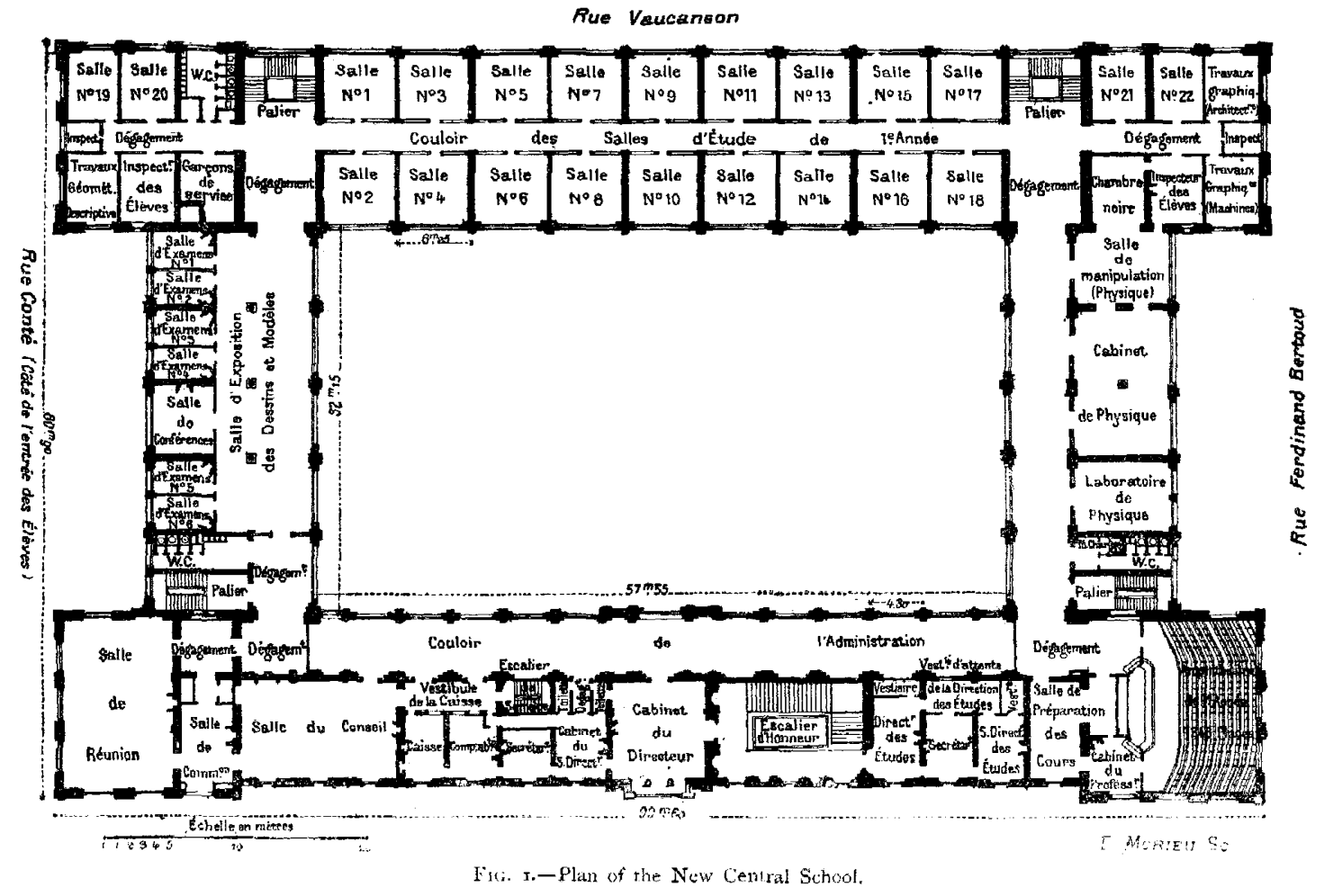

a frontage of $99^{\circ} 60 \mathrm{~m}$. and a depth of $60^{\circ} 90 \mathrm{~m}$. They are rectangular, and inclose a large central court. The first floor is reserved for the administration and for the use of the first year's students, the second for the second year's, the third for the third year's, while the fourth and highest storey is reserved for the large laboratories. The basement and ground floor are used for the mechanical appliances, the kitchen, dining halls, the collections, and small laboratories for special purposes. Taking the building more in detail, and starting with the basement, we find that its galleries contain a line of rails with small trucks, presented to the school. It is used for conveying fuel to the furnaces, and vessels full of acid to the lifts, by which they are conveyed to the laboratories. The offices of the administration are heated by hot air on the Perret-Olivier system, the apparatus being presented by the makers, while the rest of the building is heated by hot-water pipes. The basement also contains the kitchens of the rival restaurants, which are farmed out, the gas-meters, and three large Geneste and Herscher generators for heat and ventilation. The boilers aIso work the engines necessary for the generation of the 